\title{
Cytokine and Chemokine Responses in Invasive Aspergillosis Following Hematopoietic Stem Cell Transplantation: Past Evidence for Future Therapy of Aspergillosis
}

\author{
Patcharin Thammasit ${ }^{1}{ }^{\mathbb{D}}$, Jirapas Sripetchwandee ${ }^{2,3,4, *}$, Joshua D. Nosanchuk ${ }^{5} \mathbb{D}$, Siriporn C. Chattipakorn ${ }^{2,4} \mathbb{D}$, \\ Nipon Chattipakorn $2,3,4 \mathbb{D}$ and Sirida Youngchim $1, * \mathbb{D}$ \\ 1 Department of Microbiology, Faculty of Medicine, Chiang Mai University, Chiang Mai 50200, Thailand; \\ patcharin.th@cmu.ac.th \\ 2 Neurophysiology Unit, Cardiac Electrophysiology Research and Training Center, Faculty of Medicine, \\ Chiang Mai University, Chiang Mai 50200, Thailand; siriporn.c@cmu.ac.th (S.C.C.); \\ nchattip@gmail.com (N.C.) \\ 3 Cardiac Electrophysiology Unit, Department of Physiology, Faculty of Medicine, Chiang Mai University, \\ Chiang Mai 50200, Thailand \\ 4 Center of Excellence in Cardiac Electrophysiology Research, Chiang Mai University, \\ Chiang Mai 50200, Thailand \\ 5 Department of Medicine (Infectious Diseases), Albert Einstein College of Medicine, Bronx, NY 10461, USA; \\ josh.nosanchuk@einsteinmed.org \\ * Correspondence: jsripetchwandee@gmail.com (J.S.); syoungchim@gmail.com (S.Y.)
}

\section{check for} updates

Citation: Thammasit, P.; Sripetchwandee, J.; Nosanchuk, J.D.; Chattipakorn, S.C.; Chattipakorn, N.; Youngchim, S. Cytokine and Chemokine Responses in Invasive Aspergillosis Following Hematopoietic Stem Cell Transplantation: Past Evidence for Future Therapy of Aspergillosis. J. Fungi 2021, 7, 753. https://doi.org/10.3390/jof7090753

Academic Editor: Marcio Nucci

Received: 14 August 2021

Accepted: 10 September 2021

Published: 13 September 2021

Publisher's Note: MDPI stays neutral with regard to jurisdictional claims in published maps and institutional affiliations.

Copyright: (c) 2021 by the authors. Licensee MDPI, Basel, Switzerland. This article is an open access article distributed under the terms and conditions of the Creative Commons Attribution (CC BY) license (https:/ / creativecommons.org/licenses/by/ $4.0 /)$.

\begin{abstract}
Invasive pulmonary aspergillosis is a frequent complication in immunocompromised individuals, and it continues to be an important cause of mortality in patients undergoing hematopoietic stem cell transplantation. In addition to antifungal therapy used for mycoses, immune-modulatory molecules such as cytokines and chemokines can modify the host immune response and exhibit a promising form of antimicrobial therapeutics to combat invasive fungal diseases. Cytokine and chemokine profiles may also be applied as biomarkers during fungal infections and clinical research has demonstrated different activation patterns of cytokines in invasive mycoses such as aspergillosis. In this review, we summarize different aspects of cytokines that have been described to date and provide possible future directions in research on invasive pulmonary aspergillosis following hematopoietic stem cell transplantation. These findings suggest that cytokines and chemokines may serve as useful biomarkers to improve diagnosis and monitoring of infection.
\end{abstract}

Keywords: cytokines; chemokines; Aspergillus; invasive pulmonary aspergillosis; hematopoietic stem cell transplantation

\section{Introduction}

Fungi are among the most extensively distributed microorganisms and are ubiquitous in the environment. However, a small percentage of these remarkable eukaryotes are also major human pathogens. The frequency of opportunistic fungal infections continues to increase due to the expansion in the numbers of immunocompromised hosts [1]. Aspergillus species (spp.) are one of the most common medically important opportunistic fungi [2]. Invasive infections with Aspergillus spp. are typically considered life-threatening and most frequently occur in immunocompromised individuals such as those receiving chemotherapy, undergoing solid organ transplantation (SOT), or hematopoietic stem cell transplantation (HSCT) [3,4]. Among the human pathogenic species of the genus $A s-$ pergillus, Aspergillus fumigatus is the most common causative agent, followed by A. flavus, A. terreus, and A. niger [5]. In compromised hosts, Aspergillus infections most commonly manifest as invasive pulmonary aspergillosis (IPA). The number of patients undergoing transplantation has grown exponentially in recent years, particularly in patients undergo- 
ing HSCT for the treatment of hematological malignancy [6]. IPA occurs in 3.6 to $10.3 \%$ of allogeneic HSCT recipients leading to a mortality rate of 50 to $80 \%[6,7]$.

Aspergillosis is initiated by inhaling Aspergillus spores. The early immune response against Aspergillus-associated pulmonary disease is mediated by the interaction between inhaled spores (conidia) and immune effector cells [8]. Effective mechanisms of fungal clearance are regulated by the activation of inflammatory programs (e.g., NF-kB pathway and the NLRP3 inflammasome) resulting in a more robust range of pro-inflammatory cytokine and chemokine secretion by epithelial cells, inflammatory monocytes, dendritic cells (DCs), and alveolar macrophages [9]. The recognition and removal of the fungal spores occurs through (i) physical barriers and mechanical defenses of the respiratory tract, (ii) phagocytic processes, (iii) the activity of antimicrobial peptides (AMPs), and (iv) effector cell activation through engagement of pattern recognition receptors (PRRs), which include soluble receptors and cell-bound receptors [8]. The Toll-like receptor (TLR) family, one of the PRRs directed against conserved molecules in pathogens, plays a major role in the recognition of Aspergillus. These aspergillosis-related TLRs include TLR-2, TLR-4, and TLR$9[10,11]$. These TLRs potentially induce the production of pro-inflammatory cytokines and reactive oxygen species (ROS) through a MyD88-NF-kB-dependent signaling pathway [12]. In addition to these MyD88-dependent processes in macrophage-mediated responses, the uptake of $A$. fumigatus spores by respiratory epithelia plays a crucial role in either fungal killing the fungus or containing the organisms within the airway epithelial cells' (AECs) phagosome [13]. The pulmonary innate immune defense by AECs against A. fumigatus induces IL-8 secretion and is controlled by MyD88-independent kinase pathways, including PI3K, p38 MAPK, and ERK1/2 [14]. Thus, MyD88-dependent and -independent pathways are engaged in the early biological activity of Aspergillus infection and, thus, are potential therapeutic targets for disease modification.

Moreover, the protective capacity of CD4+ T cells is predominantly mediated by the secretion of a complex cytokine milieu that orchestrates a defensive response [15]. However, dysregulated production of T-helper (Th) cell cytokines is also implicated in the pathogenesis of invasive aspergillosis (IA) [8]. The interplay between environmental conditions, fungal virulence factors, and the host immune response plays a crucial role in the pathogenesis of IA through a variety of mechanisms [9]. Furthermore, cytokine production by $\mathrm{CD} 4+\mathrm{T}$ helper cells is required for the initiation of the innate response in the IA mouse model [16], as well as in the serum of patients suffering from IPA, compared to healthy individuals $[17,18]$. Since cytokines act as important mediators of an effective immune response and the regulators for the innate and adaptive immune system [19], the dynamic of cytokines appears to play an important role in the host immune response against Aspergillus. Relatively immunocompromised hosts, such as patients undergoing SOT or HSCT, present host conditions that contribute to the overall pathogenic potential of Aspergillus infection. HSCT, in particular, is known as a primary immune deficiency exacerbated by the administration of immunosuppressive drugs, resulting in significant CD8 regulatory $\mathrm{T}$ cell (Tregs) dysfunction and phagocytic cell defects [20]. Therefore, the complex cytokine and chemokine behaviors produced in response to IA have provided crucial insights into the pathogenesis of IA, and the tracking of changes in these molecules may potentially help guide clinicians in decisions regarding the prophylaxis for and treatment of aspergillosis, especially in HSCT patients.

\section{Cytokines and Chemokines Responses in Invasive Aspergillosis after Hematopoietic Stem Cell Transplantation}

Cytokines and chemokines are biologically active secreted proteins released by immune cells that play critical roles in cell-to-cell communication. In aspergillosis, they are an important component of host defenses against infection by promoting the initiation, maintenance, and resolution of the host response [21]. Innate immune cells composed of granulocytes, monocytes, AECs, and DCs are the first line of defense against Aspergillus and are the cells that primarily combat the fungus within the first week after infection [21]. In addition, macrophages phagocytose Aspergillus conidia and inhibit their intracellular 
germination in the early phase of infection [22], which induces the expression of inflammatory chemokines and cytokines. Furthermore, neutrophils and circulating monocytes damage hyphae by secreting oxidative and non-oxidative microbicidal compounds [23]. Hence, early neutropenia followed by immunosuppressive drugs in HSCT leads to defects in certain immune-related phagocytosis. Thus, these findings indicate that the association between HSCT and the immune system is highly dynamic [24].

The results from in vitro analyses reveal that infection of the immature dendritic cells (iDCs) with small germinating conidia (approximate size, 3-8 $\mu \mathrm{m}$ ) significantly increased the secretion of specific cytokines (IL-6, IL-12, TNF- $\alpha$, and IL-10) and chemokines (IL-8, CCL20, and CXCL10) and the expression of immune receptors (PTX3, CXCR4, CCRL2, and IL2RA) [25]. The significant increase of both the pro-inflammatory cytokine TNF- $\alpha$ and chemoattraction chemokines IL-8, CCL-20, and CXCL10 were also observed with stimulation by the Aspergillus antigen 18-kDa RNase Aspf1 [26], compared to the levels expressed by unstimulated DCs.

Natural killer (NK) cells are lymphoid cells in peripheral blood that play a critical role in the innate host defense and their cell numbers are related to the severity of IPA [24]. NK cells are known for their release of cytokines and play a unique role in the early phase of an immune response against Aspergillus [27]. In vitro infection of human NK cells by $A$. fumigatus hyphae for $6 \mathrm{~h}$ increases the secretion of inflammatory cytokines, such as IFN- $\gamma$, TNF- $\alpha$, and growth factor GM-CSF, as well as several chemokines, including CXCL8/IL-8, CCL3/MIP-1 $\alpha$, CCL4/MIP-1 $\beta$, and XCL1/lymphotactin [27]. Supporting the results from in vitro studies, a murine intranasal infection model using $A$. fumigatus conidia suggested that susceptibility to IA is associated with the levels of genes encoding IL-5 (a Th2 cytokine involved in B cell and eosinophil activation) and IL-17a (a Th17 inflammatory cytokine produced by T cells and NK cells). The increased expressions of the genes encoding IFN- $\gamma$, high levels of TNF- $\alpha$ and the upregulation of a network of TNF$\alpha$-related genes were significantly related to Aspergillus infection [28]. Additionally, the expression of classical Th2 cytokines (IL-4, IL-5, IL-13) was found in bronchiole epithelial lung homogenates of Aspergillus protease-induced murine inhalation model compared to the PBS-treated controls [29].

Several studies have demonstrated an alteration of cytokines and chemokines in patients with hematological malignancy undergoing HSCT who subsequently develop invasive fungal disease $[18,30,31]$ and IA in particular $[18,32,33]$. For example, in adult hematology patients with proven/probable invasive fungal disease (IFD), increases of serum cytokine levels of IL-15 and IL-2R as well as chemokines levels of CCL2 and MIP-1 $\alpha$ were observed, whereas the level of IL-4 was significantly lowered, compared to those with no evidence of IFD [18]. Another study in adult hematology patients with probable/possible IA reported higher levels of cytokine IL-6 and chemokine IL-8 in serum and significant elevations in bronchoalveolar lavage (BAL) fluid levels of IL-8, compared to those with other infections [32]. In support of these findings, Gonçalves et al. demonstrated that the BAL fluid levels of cytokines IL-1 $\beta$, IL-6, IL-17A, IL-23, TNF- $\alpha$, and chemokine IL-8 were increased in patients diagnosed with IA, which were also consistent with levels of these cytokines in serum [33]. Notably, although the expression of in vitro and in vivo cytokines/chemokines varies in the different studies, these discrepancies may be explained by differences in cell types responding to Aspergillus stimuli and the different patient populations. However, all these laboratory findings suggest that the elevation of cytokines/chemokines in serum and BAL fluid levels were associated with increased risk of IA and, thus, may be used as a valuable indicator of the risks associated with development of IA and guide enhanced antifungal prophylaxis and early treatment. These findings are summarized in Table 1. 
Table 1. Cytokine and chemokine responses in invasive aspergillosis after hematopoietic stem cell transplantation.

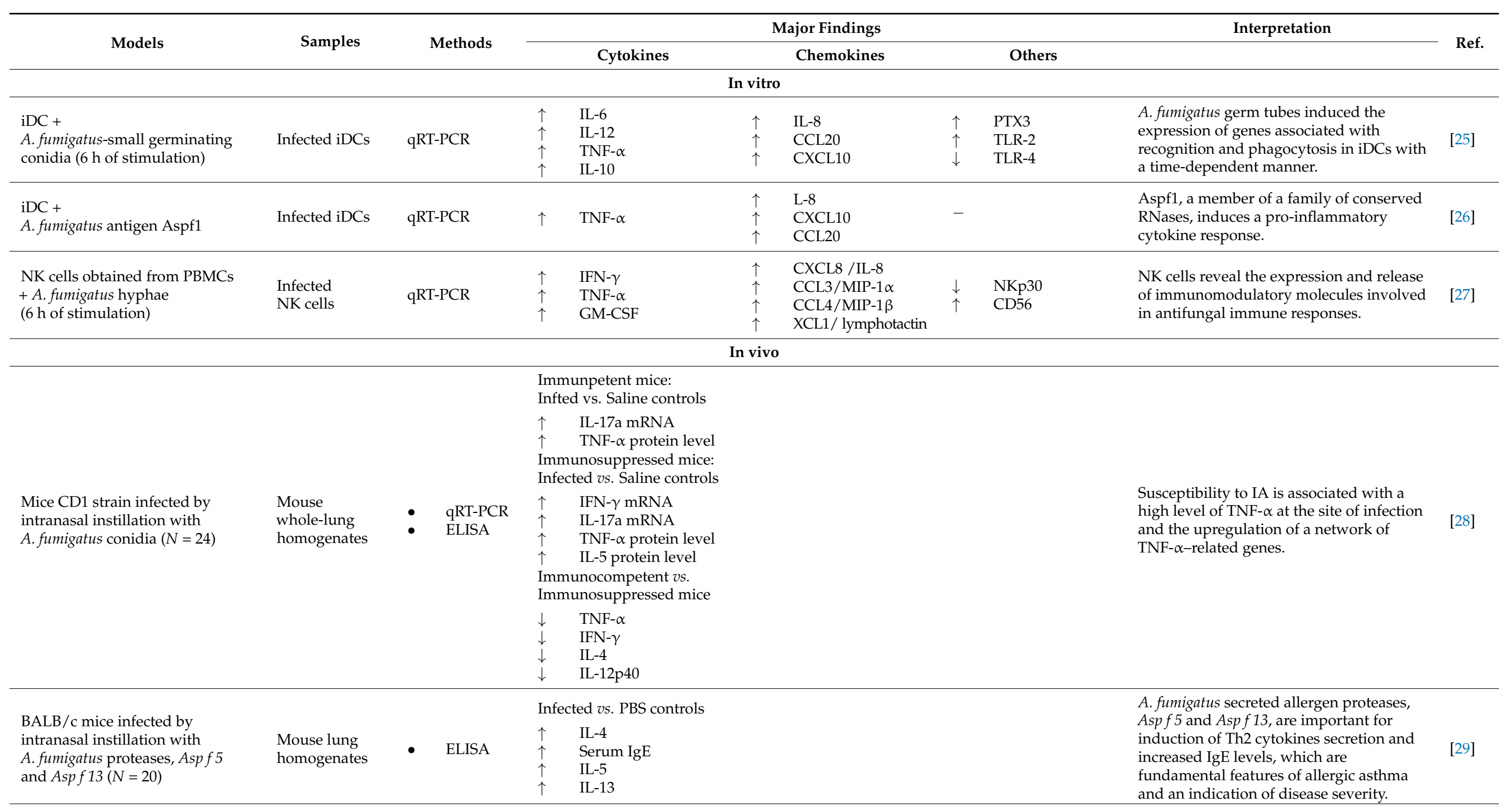


Table 1. Cont.

\begin{tabular}{|c|c|c|c|c|c|c|c|c|}
\hline \multirow{2}{*}{ Models } & \multirow{2}{*}{ Samples } & \multirow{2}{*}{ Methods } & \multicolumn{4}{|c|}{ Major Findings } & \multirow[t]{2}{*}{ Interpretation } & \multirow{2}{*}{ Ref. } \\
\hline & & & Cytokines & Chemokines & & Others & & \\
\hline \multicolumn{9}{|c|}{ In vitro } \\
\hline \multicolumn{9}{|c|}{ Clinical study } \\
\hline $\begin{array}{l}\text { Adult hematology patients } \\
\text { with proven/probable IFD } \\
(N=172)\end{array}$ & Serum & ELISA & $\begin{array}{ll}\uparrow & \text { IL-15 } \\
\uparrow & \text { IL-2R } \\
\downarrow & \text { IL-4 }\end{array}$ & $\begin{array}{ll}\uparrow & \text { CCL2 } \\
\uparrow & \text { MIP-1 } \alpha\end{array}$ & - & & $\begin{array}{l}\text { High IL-2R and CCL2 concentrations } \\
\text { as indicators for the risk of } \\
\text { developing IFD. }\end{array}$ & [18] \\
\hline $\begin{array}{l}\text { Patients diagnosed with IA } \\
(N=48)\end{array}$ & $\begin{array}{ll}- & \text { BAL } \\
- & \text { Serum }\end{array}$ & ELISA & \begin{tabular}{ll}
\multicolumn{2}{l}{ BAL } \\
$\uparrow$ & IL-1 $\beta$ \\
$\uparrow$ & IL-6 \\
$\uparrow$ & IL-17A \\
$\uparrow$ & IL-23 \\
$\uparrow$ & TNF- $\alpha$ \\
$\uparrow$ & \\
Serum \\
$\uparrow$ & IL-6 \\
$\uparrow$ & IL-17A \\
$\uparrow$ & IL-23
\end{tabular} & $\begin{array}{l}\text { BAL } \\
\uparrow \quad \text { IL-8 } \\
\text { Serum } \\
\uparrow \quad \text { IL-8 }\end{array}$ & $\uparrow$ & $\begin{array}{l}\text { Galactomannan } \\
\text { in BAL } \\
\text { specimens }\end{array}$ & $\begin{array}{l}\text { Alveolar cytokines might be useful in } \\
\text { supporting current diagnostic } \\
\text { approaches for IPA biomarkers. } \\
\text { IL- } 8 \text { was the best performing analyte } \\
\text { with the most relevant discriminator } \\
\text { between cases of IPA and controls. }\end{array}$ & [33] \\
\hline
\end{tabular}

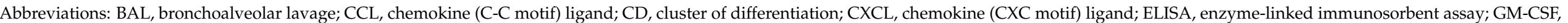

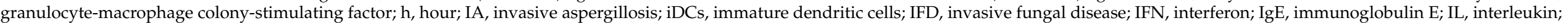

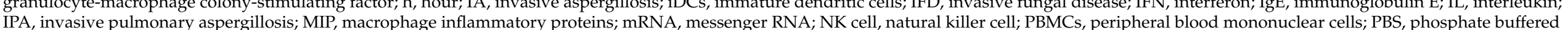

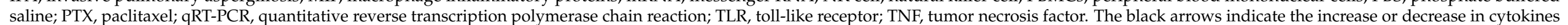
and chemokines. 


\section{Genetic Polymorphisms in Hematopoietic Stem Cell Transplantation Patients Associated with Invasive Aspergillosis}

Given the variable risk of infection and its clinical outcome among patients with comparable predisposing factors, genetic predisposition is considered as the most important factor of individual susceptibility to IA [34]. Aspergillus conidia or hyphae interact with the innate immune system through PRRs, which included Dectin-1, TLR-2, and TLR-4 [35]. These TLRs can trigger PI3K, MAPK, and ERK1/2 signaling pathways, resulting in the production of several cytokines and chemokines including IL-8, IL-1 $\alpha$, IL-1 $\beta$, IL-17, TNF- $\alpha$, CCL3, CCL4, as well as CXCL1 from immune cells [36,37]. Dectin-1 is an NK-cell-receptorlike C-type lectin that is widely expressed on monocytes, macrophages, DCs, neutrophils, and eosinophils [38]. Dectin-1 mediates antifungal immunity through the promotion of inflammatory activity, eventually leading to fungal clearance. Antifungal immunity can occur through the triggering of Syk, which leads to the induction of NF- $\mathrm{kB}$ and production of protective cytokine responses. Dectin- 1 signals and induces the production of cytokines through a Syk-independent pathway (noncanonical NF- $\kappa B$ pathway) [39]. Therefore, genetic polymorphisms affecting human Dectin- 1 can be partly attributed to defective cytokine production, leading to an increased susceptibility to IA. Defective production of TNF- $\alpha$ and IL- 6 has been found in both PBMCs and BEAS-2B respiratory epithelial cells harboring the Dectin-1 Y238X polymorphism [40,41]. Additionally, Dectin-1 knockout in BALB/c mice have decreased production of IFN- $\gamma$, IL-17A, and IL-10, and have a significantly reduced ability to control Aspergillus infection [41]. Conversely, single nucleotide polymorphisms (SNPs) in the intracellular PRR NOD2 can decrease the risk of IA [35]. NOD2 deficiency results in a defective inflammatory response with alterations in the levels of IL-1 $\beta$, IL-17A, IL-22, and IFN- $\gamma$ produced by PBMCs from hematological patients undergoing allogeneic HSCT, and IL-6 and TNF levels in Nod2 ${ }^{-/-}$deficient mice [42]. Furthermore, low levels of serum IL-10 and IL-8 have been reported in patients with hematological malignancies undergoing allogeneic HSCT [42]. Thus, targeting assays for alternations in NOD2 may be an attractive method in personalized management strategies for IA. However, at present, these findings fundamentally show that defects in NOD2 potentially reduce Aspergillus-induced cytokine driven inflammation. Importantly, it needs to be elucidated whether cytokine alterations mechanistically protect from fungal infection in HSCT patients with NOD2 variants. Furthermore, polymorphisms in other cytokine genes such as IL-1 and IL-10 have also been implicated as genetic biomarkers of susceptibility to IFD $[43,44]$. These findings are summarized in Table 2. 
Table 2. Genetic polymorphisms in hematopoietic stem cell transplantation patients are associated with susceptibility/resistance to invasive aspergillosis.

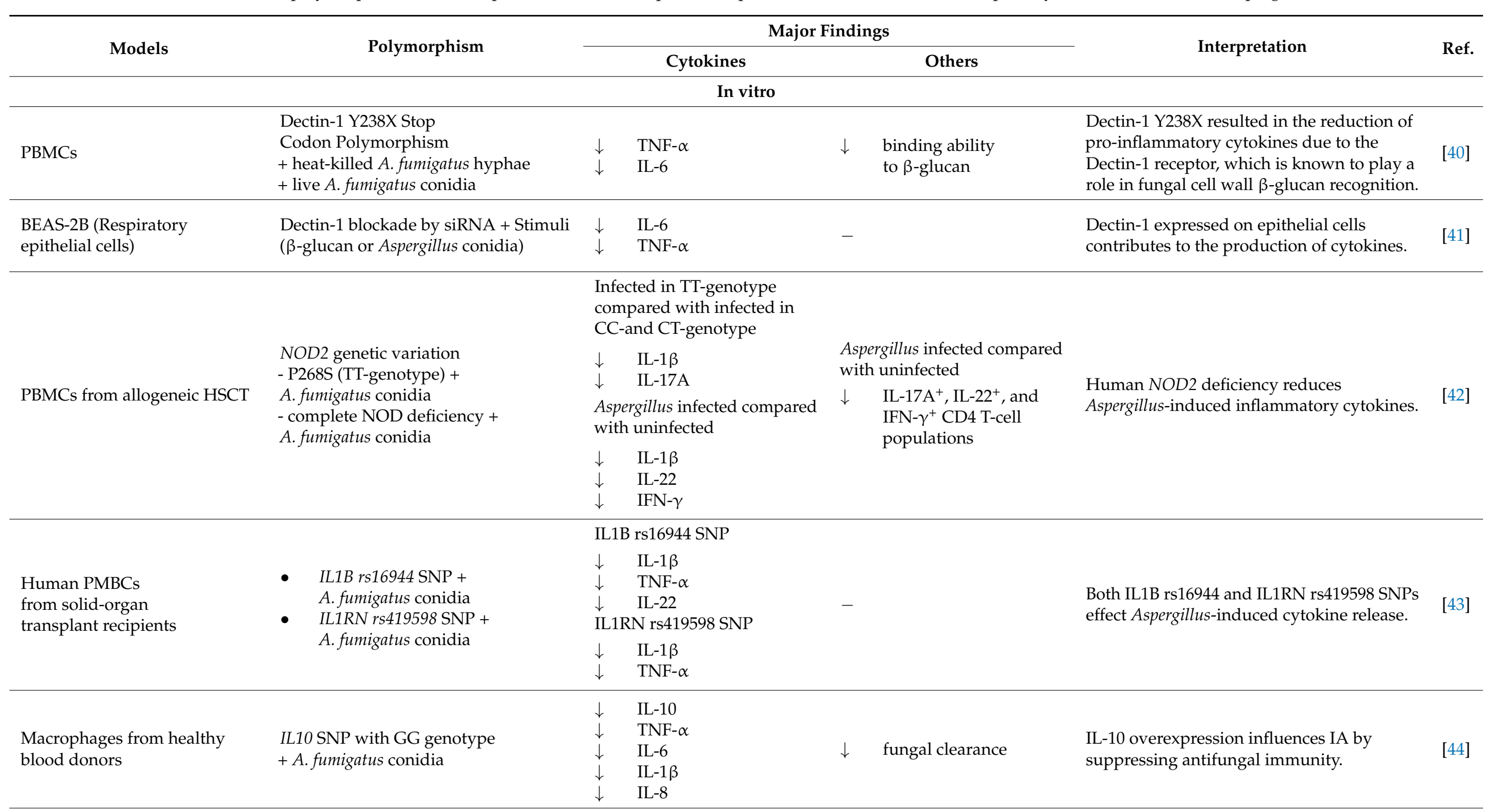


Table 2. Cont.

\begin{tabular}{|c|c|c|c|c|c|c|c|}
\hline \multirow{2}{*}{ Models } & \multirow{2}{*}{ Polymorphism } & \multicolumn{4}{|c|}{ Major Findings } & \multirow{2}{*}{ Interpretation } & \multirow{2}{*}{ Ref. } \\
\hline & & & Cytokines & & Others & & \\
\hline \multicolumn{8}{|c|}{ In vitro } \\
\hline $\begin{array}{l}\text { BALB/c mice with HSCT } \\
+ \text { Aspergillus }(N=16)\end{array}$ & Dectin-1 knockout mice & $\begin{array}{l}\downarrow \\
\downarrow \\
\downarrow\end{array}$ & $\begin{array}{l}\text { IFN- } \gamma \\
\text { IL-17A } \\
\text { IL-10 }\end{array}$ & $\uparrow$ & fungal growth & $\begin{array}{l}\text { Dectin- } 1 \text { modulates immunity and tolerance } \\
\text { via IFN- } \gamma \text { / IL-10 production, and both } \\
\text { cytokines activate the protection of } \\
\text { Th1/Treg antifungal responses. }\end{array}$ & {$[41]$} \\
\hline $\begin{array}{l}\text { Nod2-deficient }\left(\mathrm{Nod2}^{-/-}\right) \\
\text {C57BL } / 6 \text { mice } \\
+ \text { Aspergillus (lethal dose) } \\
(N=22)\end{array}$ & Nod2//- deficient mice (Splenocytes) & $\begin{array}{l}\downarrow \\
\downarrow\end{array}$ & $\begin{array}{l}\text { IL-6 } \\
\text { TNF }\end{array}$ & $\uparrow$ & 14-day survival & $\begin{array}{l}\text { NOD2 augments Aspergillus-induced } \\
\text { cytokine responses and results in resistance } \\
\text { to Aspergillus infection. }\end{array}$ & [42] \\
\hline \multicolumn{8}{|c|}{ Clinical study } \\
\hline $\begin{array}{l}\text { Patients who developed IA } \\
\text { post HSCT }(N=71) \\
\text { Non-HSCT patients with IA } \\
(N=21)\end{array}$ & Y238X Stop Codon Polymorphism & - & & $\uparrow$ & susceptibility to IA & $\begin{array}{l}\text { Dectin-1 Y238X heterozygosity had a limited } \\
\text { influence on susceptibility to IA. }\end{array}$ & [45] \\
\hline $\begin{array}{l}\text { An allograft with IA } \\
(N=81) \\
\text { or without IA } \\
(N=58)\end{array}$ & $\begin{array}{l}\text { CXCL10 genetic variation } \\
-\mathrm{C}+11101 \mathrm{~T} \\
-\mathrm{C}+1642 \mathrm{G} \\
-\mathrm{A} 1101 \mathrm{G}\end{array}$ & $\uparrow$ & serum CXCL-10 & $\uparrow$ & susceptibility to IA & $\begin{array}{l}\text { Polymorphisms in CXCL10 altered } \\
\text { chemokine secretion and increased the risk } \\
\text { of IA after alloSCT. }\end{array}$ & {$[40]$} \\
\hline
\end{tabular}

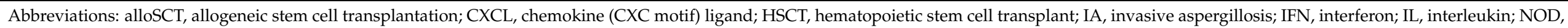

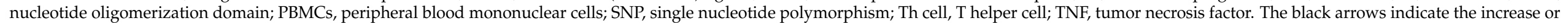
decrease in cytokines and chemokines. Nod2 $\%$ indicates complete deletion (-) of Nod2 alleles. 


\section{Drug-Related Cytokine Alterations in Developing Invasive Aspergillosis in Hematopoietic Stem Cell Transplantation Patients}

Diverse medications are administered to patients undergoing HSCT, and many of these are immunomodulatory and impair inflammatory responses. For example, the TNF$\alpha$ receptor blocker etanercept has emerged as a useful therapeutic for chronic and acute graft-versus-host disease (GvHD) management, and it also has a significant influence on the immune response against Aspergillus [46]. Etanercept fuses to the TNF receptor 2 to block the release of this key pro-inflammatory cytokine, and the reduction of TNF- $\alpha$ limits its downstream signaling including impairing NF- $\kappa$ B activation [47]. A recent in vitro study using monocyte-derived macrophages (MDM) stimulated with $A$. fumigatus showed a significant reduction of chemokine CXCL10 release after etanercept application [46]. Consistent with the in vitro results, patients receiving etanercept with probable IA have reduced CXCL10 serum concentrations [46]. Hence, etanercept administration markedly reduces CXCL10 level, which is associated with a decreased potency of host defensive mechanisms against Aspergillus. These effects may be partly explained by the important role of TNF- $\alpha$ in activating CXCL10 secretion via the STAT1-NF- $k B 1(p 50)-R e l A(p 65)$ pathway [48]. CXCL10 exhibits a strong chemotactic property for immune cells, which is important for defense against fungal infection [49].

Cyclosporine is another medication frequently administered in the setting of HSCT. Cyclosporine treatment in an anti-Aspergillus $\mathrm{T}_{\mathrm{H}} 1$ model using cells isolated from normal human volunteers revealed that this immunosuppressant significantly reduced the number of IFN- $\gamma$ producing cells and suppressed the levels of the cytokine. Furthermore, cyclosporine significantly decreased the expression of CD154 and increased apoptosis rate on anti-Aspergillus $\mathrm{T}_{\mathrm{H}} 1$ cells [50]. These modifications induced by cyclosporine increase the risk for IA.

Recombinant human granulocyte colony stimulating factor (r-metHuG-CSF, or GCSF) has been widely used to mitigate radiation-induced oropharyngeal mucositis. In contrast to etanercept and cyclosporine, GCSF enhances the activities of neutrophils against Aspergillus infection by increasing the number of mature neutrophils, enhancing phagocyte oxidative responses and increasing phagocytic activity [51]. These responses are associated with a benefit for the prevention and treatment of IA in transplant patients who display an impaired respiratory burst [52]. In addition, a recent in vivo study demonstrated that macrophage colony-stimulating factor (M-CSF) also has a therapeutic benefit against Aspergillus in HSCT and progenitor cells-transplanted mice by inducing the differentiation of myeloid progenitor cells [53]. Thus, administration of M-CSF not only reduced graftversus-host disease in HSCT [54], but it can augment protective effector responses to Aspergillus after HSCT in patients.

In summary, the drugs administered to HSCT patients may significantly influence their risk for IA, and drug regimens should be considered for the personalized risk stratification protocols in these patients. These findings are summarized in Table 3. 
Table 3. Drug-related cytokine alterations associated with invasive aspergillosis in hematopoietic stem cell transplantation patients.

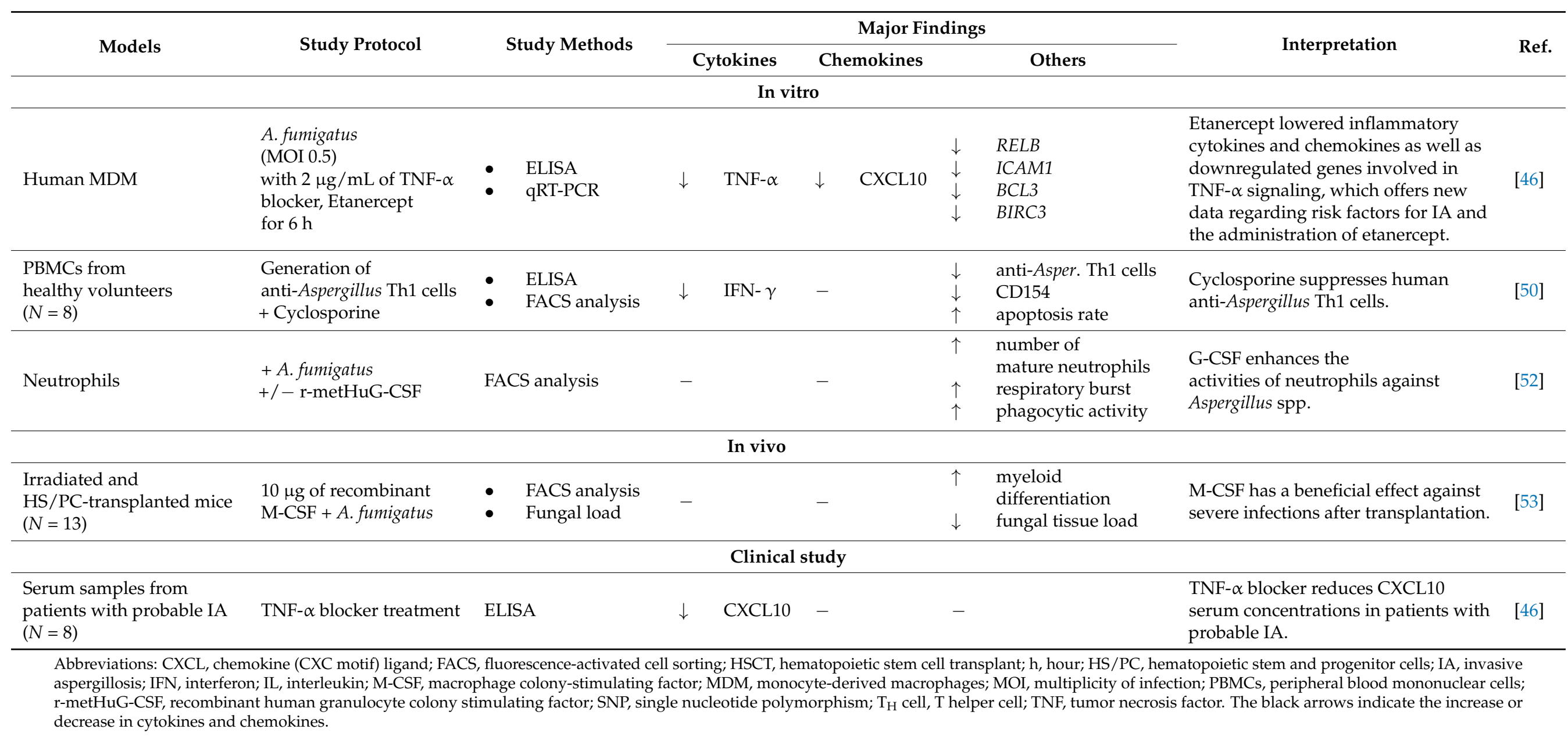


5. Pattern of Cytokine Production in Dendritic Cells (DCs) Activation for Vaccine Prospects against Invasive Aspergillosis in Hematopoietic Stem Cell Transplantation

Cell-mediated immunity (CMI) plays a vital role in protection against Aspergillus [55]. The cellular response of the airway bronchial epithelial cells to Aspergillus is the first layer of protection against the pathogen. The major roles of bronchial epithelial cells include enhancing recruitment of macrophages and neutrophils, increasing the release of proinflammatory cytokines and chemokines, and activating and skewing T-cell subsets [56]. The engulfment of conidia and/or hyphae by alveolar macrophages leads to the release of numerous cytokines and chemokines that further enhance the recruitment of innate effector cells including macrophages and DCs [57]. DCs act as the key player in connecting innate and adaptive immune response against Aspergillus by specifically activating naive T-cells and their differentiation into an effector lineage [58].

Several reports from in vitro studies have demonstrated that murine and human DCs are activated by $A$. fumigatus morphotypes [59-62]. Murine DCs increased their production of IL-10 and IL-12 in response to Aspergillus conidia, and hyphae stimulated the production of both IL-4 and IL-10. Human DCs are also responsible for the initiation of both the innate and the adaptive immune response [59-62]. The differences in cytokine production patterns for conidia and hyphae might be explained by the variable functional activation of DCs in response to the different morphotypes of $A$. fumigatus. For example, these cells may internalize conidia or hyphae of Aspergillus via different phagocytic mechanisms, and engage PRRs [63]. In addition, DCs also play an important role in Th17 polarization during A. fumigatus infection [64]. Activation of IL-17 cytokine leads to the recruitment of neutrophils and increased concentrations of defensins that ultimately cause inflammation. A heightened IL-23/IL-17-dependent inflammatory response is also associated with susceptibility to aspergillosis in the mice model, and modulation of these cytokines is essential in the early control of the infection $[65,66]$. Consequently, these differences in interactions of DCs can lead to divergent patterns of cytokine production. DC vaccines for fungal diseases are an exciting therapeutic approach to protect compromised patients [67]. The power of DC vaccines is demonstrated by the striking capacity of primed DCs to protect HSCT mice. Perruccio et al. demonstrated that the infusion of murine splenic DCs infected with $A$. fumigatus conidia decreased lung CFUs and increased the median survival time of HSCT mice with IA [59]. DC vaccination also increased the levels of IFN- $\gamma$ and IL-10, and demonstrated a Th1-protective response [59]. Others have reported that murine splenic DCs infected with $A$. fumigatus produced increased amounts of IFN- $\gamma$ and IL-4 after internalization of conidia [61]. Murine splenic DCs only increase IL-4 after internalization of hyphae [61]. Interestingly, adoptive transfer in vivo of purified DCs pulsed with conidia or hyphae resulted in priming of CD4+ T cells for Th1 cytokine (IFN- $\gamma$ and TNF- $\alpha$ ) or Th2 cytokine (IL-4 and IL-10) production, respectively, which is similar to what was described above for in vitro DC responses to these morphotypes. Hence, these results underscore the major role of DCs in the polarization of T cells and patterns of susceptibility or resistance during IA [68]. These findings also reinforce that morphogenesis is a key fungal virulence factor as the transition from conidia to hyphae induces different host responses and the host must alter immunological tactics in order to control disease.

These studies confirm that DCs are important for host response against Aspergillus and suggest that the functional plasticity of DCs in response to Aspergillus infection can be potentially therapeutically exploited. Ex vivo-generated and primed DCs, in particular, might be useful for restoring pathways of cell-mediated immunity or enhancing antifungal immunity following HSCT. These findings are summarized in Table 4. 
Table 4. Perspective of vaccine development using dendritic cells (DCs) activation and its impact on cytokine levels in invasive aspergillosis.

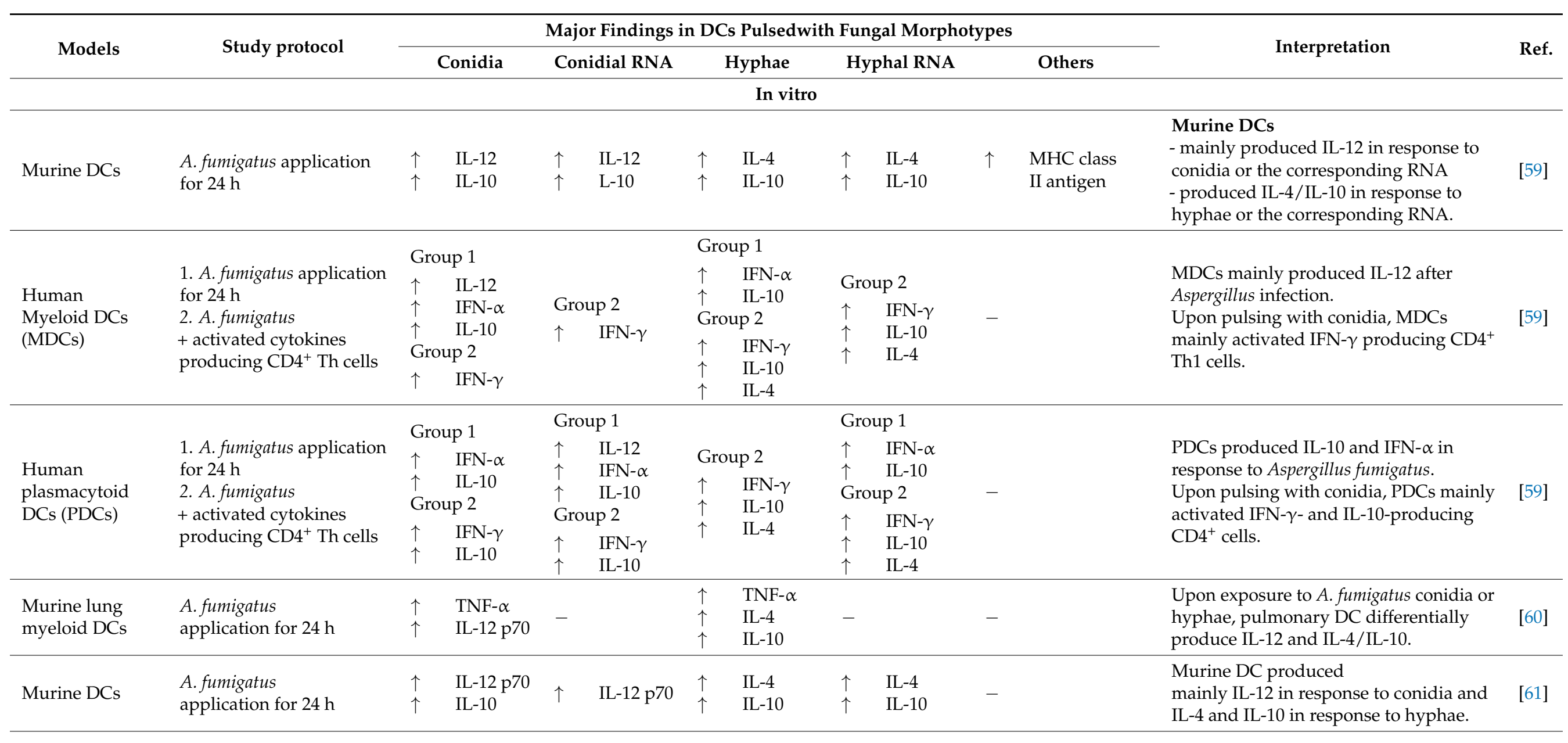


Table 4. Cont.

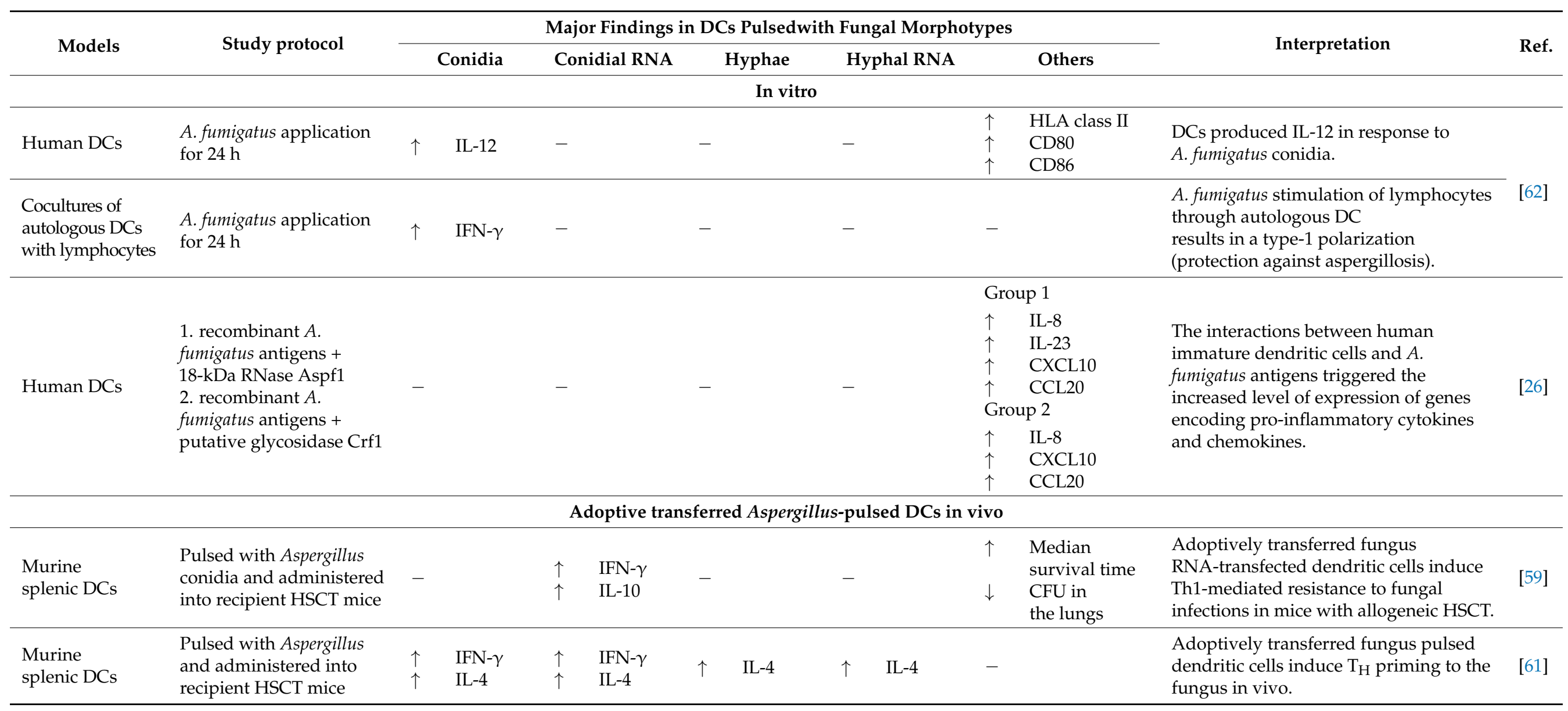

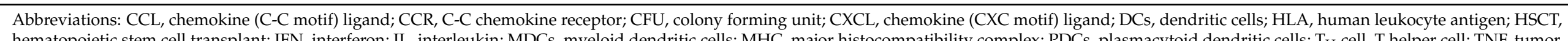

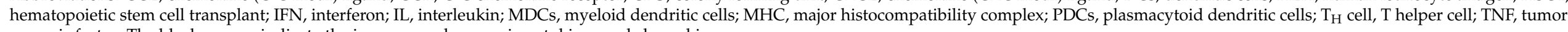
necrosis factor. The black arrows indicate the increase or decrease in cytokines and chemokines. 


\section{Conclusions and Perspectives}

A correlation of certain infectious diseases with an alteration of cytokine profiles has been deemed clinically useful for disease management, with COVID-19 being the most recent example where modifying specific cytokines can effectively mitigate disease [69,70]. One of the major roles of cytokines in the immune system, as immune regulators, are their pleiotropic effects, which include immunologic, hematopoietic, and pro-inflammatory activities. IA is correlated with remarkable cytokine alterations, as reflected by the dynamic changes in cytokine and chemokine levels. Alterations in immunity, particularly defects in innate immunity, is one of the concerning factors following HSCT and this immune compromise significantly increases risk for IA. The findings in this review, especially the data on IL-8 and pro-inflammatory cytokines (IFN- $\gamma$, TNF- $\alpha$, and IL-6), could therefore be considered a biological characteristic that may serve as a platform for, primarily, analysis of patients targeted for IA monitoring. Additionally, these molecules and associate pathways are attractive potential therapeutic targets for modifying the pathogenesis of IA. Nevertheless, other confounding factors such as drugs being administered to patients and genetic polymorphisms in patients should be considered, as these will alter biological response patterns (see Figure 1). Hence, there is an urgent need to better understand the different contributions of the various factors-host and therapeutics - that underly the cytokine signaling pathways in these patients with and without IA. Furthermore, it is important to consider that other invasive fungal infections, and some bacterial pathogens, may trigger host immune responses with similar immune response profiles. Thus, the assumption that there is a causal association between particular cytokine/chemokine profiles and the specific occurrence, development, and resolution of IA requires further investigation. Additionally, research is required to identify the cut-off levels of the key cytokines for their use as diagnostic tools in HSCT patients with IA. This review highlights that targeting cytokine alterations is a promising method for predicting the risk for, and progression of, IA in HSCT patients, and this approach may also be used to monitor the efficacy of antifungal prophylaxis and therapy.

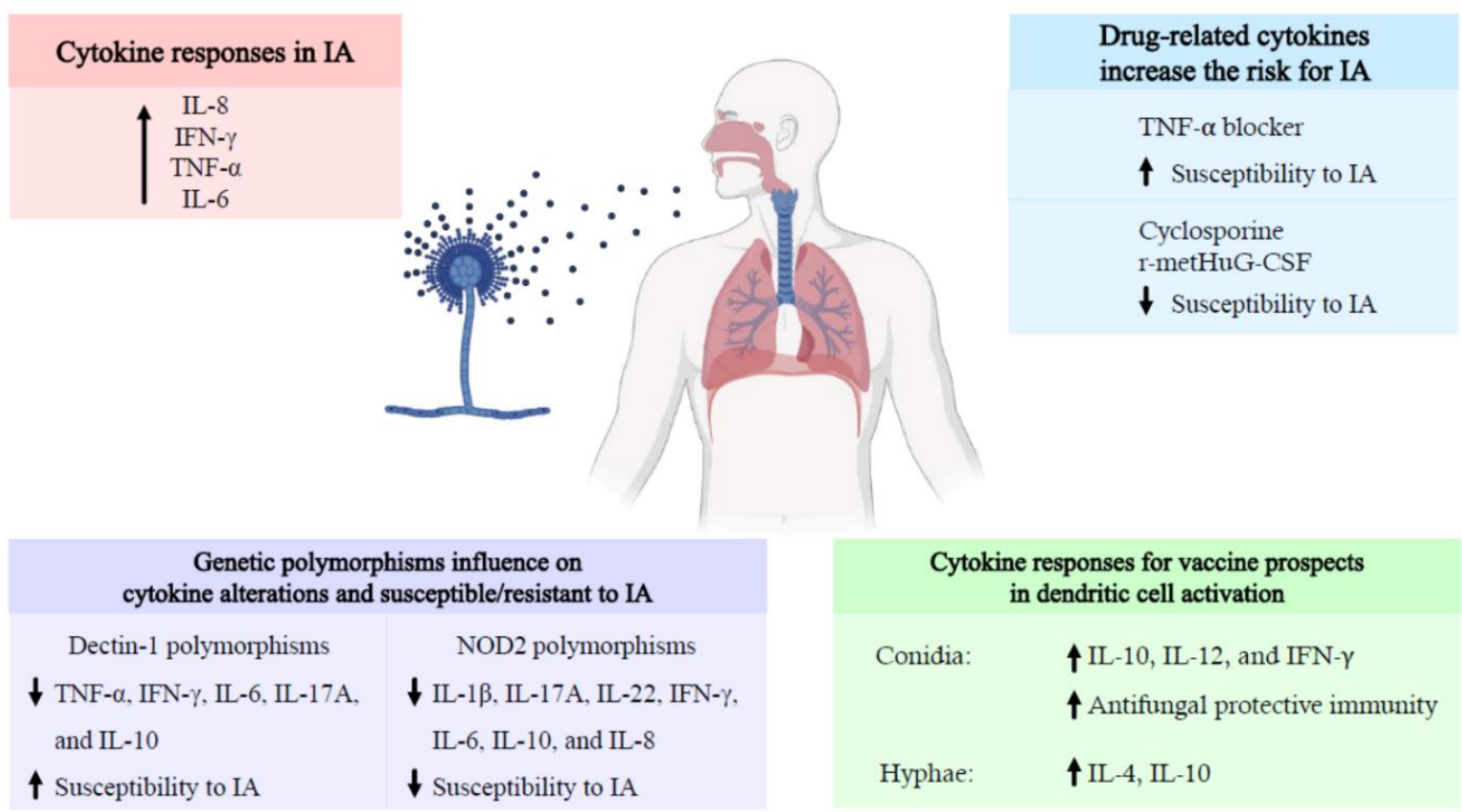

Figure 1. Schematic representation of the cytokine responses associated with invasive aspergillosis in hematopoietic stem cell transplantation. Cytokine responses related to invasive aspergillosis associated with an increase the risk of the disease. Both drugs and genetic polymorphism influence the cytokine expression profile during hematopoietic stem cell transplantation. In addition, different activation patterns of Aspergillus morphotypes lead to different cytokine expression profiles. Abbreviations: IA, invasive aspergillosis; IFN, interferon; IL, interleukin; NOD2, nucleotide oligomerization domain 2; r-metHuG-CSF, recombinant human granulocyte colony stimulating factor; TNF, tumor necrosis factor. The black arrows indicate the increase or decrease in cytokines and chemokines. 
Author Contributions: Conceptualization, P.T., S.C.C., and N.C.; writing-original draft preparation, P.T., and J.S.; writing-review and editing, S.C.C., N.C., J.D.N., and S.Y. All authors have read and agreed to the published version of the manuscript.

Funding: This study was supported by a research grant from Chiang Mai University, Chiang Mai, Thailand (SY); the NSTDA Research Chair Grant from the National Science and Technology Development Agency (NC); the Senior Research Scholar Grant from the National Research Council of Thailand (SCC); and the Chiang Mai University Center of Excellence Award (NC).

Institutional Review Board Statement: Not applicable.

Informed Consent Statement: Not applicable.

Data Availability Statement: Not applicable.

Conflicts of Interest: The authors declare no conflict of interest.

\section{References}

1. Badiee, P.; Hashemizadeh, Z. Opportunistic invasive fungal infections: Diagnosis \& clinical management. Indian J. Med. Res. 2014, 139, 195-204. [PubMed]

2. Weaver, J.D.; Mullaney, E.J.; Lei, X.G. Altering the substrate specificity site of Aspergillus niger PhyB shifts the pH optimum to pH 3.2. Appl. Microbiol. Biotechnol. 2007, 76, 117-122. [CrossRef] [PubMed]

3. Fishman, J.A. Infection in solid-organ transplant recipients. N. Engl. J. Med. 2007, 357, 2601-2614. [CrossRef] [PubMed]

4. Stuehler, C.; Kuenzli, E.; Jaeger, V.K.; Baettig, V.; Ferracin, F.; Rajacic, Z.; Kaiser, D.; Bernardini, C.; Forrer, P.; Weisser, M.; et al. Immune reconstitution after allogeneic hematopoietic stem cell transplantation and association with occurrence and outcome of invasive aspergillosis. J. Infect. Dis. 2015, 212, 959-967. [CrossRef] [PubMed]

5. Morgan, J.; Wannemuehler, K.A.; Marr, K.A.; Hadley, S.; Kontoyiannis, D.P.; Walsh, T.J.; Fridkin, S.K.; Pappas, P.G.; Warnock, D.W. Incidence of invasive aspergillosis following hematopoietic stem cell and solid organ transplantation: Interim results of a prospective multicenter surveillance program. Med. Mycol. 2005, 43 (Suppl. 1), S49-S58. [CrossRef]

6. Singh, N.; Paterson, D.L. Aspergillus infections in transplant recipients. Clin. Microbiol. Rev. 2005, 18, 44-69. [CrossRef]

7. Lin, S.J.; Schranz, J.; Teutsch, S.M. Aspergillosis case-fatality rate: Systematic review of the literature. Clin. Infect. Dis. 2001, 32, 358-366. [CrossRef] [PubMed]

8. Chotirmall, S.H.; Al-Alawi, M.; Mirkovic, B.; Lavelle, G.; Logan, P.M.; Greene, C.M.; McElvaney, N.G. Aspergillus-associated airway disease, inflammation, and the innate immune response. Biomed Res. Int. 2013, 2013, 723129. [CrossRef] [PubMed]

9. Al-Bader, N.; Sheppard, D.C. Aspergillosis and stem cell transplantation: An overview of experimental pathogenesis studies. Virulence 2016, 7, 950-966. [CrossRef] [PubMed]

10. Meier, A.; Kirschning, C.J.; Nikolaus, T.; Wagner, H.; Heesemann, J.; Ebel, F. Toll-like receptor (TLR) 2 and TLR4 are essential for Aspergillus-induced activation of murine macrophages. Cell Microbiol. 2003, 5, 561-570. [CrossRef] [PubMed]

11. Bellocchio, S.; Moretti, S.; Perruccio, K.; Fallarino, F.; Bozza, S.; Montagnoli, C.; Mosci, P.; Lipford, G.B.; Pitzurra, L.; Romani, L. TLRs govern neutrophil activity in aspergillosis. J. Immunol. 2004, 173, 7406-7415. [CrossRef] [PubMed]

12. Willment, J.A.; Brown, G.D. C-type lectin receptors in antifungal immunity. Trends Microbiol. 2008, 16, 27-32. [CrossRef] [PubMed]

13. Bertuzzi, M.; Hayes, G.E.; Icheoku, U.J.; van Rhijn, N.; Denning, D.W.; Osherov, N.; Bignell, E.M. Anti-Aspergillus activities of the respiratory epithelium in health and disease. J. Fungi 2018, 4, 8. [CrossRef]

14. Balloy, V.; Sallenave, J.M.; Wu, Y.; Touqui, L.; Latge, J.P.; Si-Tahar, M.; Chignard, M. Aspergillus fumigatus-induced interleukin-8 synthesis by respiratory epithelial cells is controlled by the phosphatidylinositol 3-kinase, p38 MAPK, and ERK1/2 pathways and not by the toll-like receptor-MyD88 pathway. J. Biol. Chem. 2008, 283, 30513-30521. [CrossRef] [PubMed]

15. Chai, L.Y.; van de Veerdonk, F.; Marijnissen, R.J.; Cheng, S.C.; Khoo, A.L.; Hectors, M.; Lagrou, K.; Vonk, A.G.; Maertens, J.; Joosten, L.A.; et al. Anti-Aspergillus human host defence relies on type $1 \mathrm{~T}$ helper (Th1), rather than type 17 T helper (Th17), cellular immunity. Immunology 2010, 130, 46-54. [CrossRef]

16. Cenci, E.; Mencacci, A.; Fe d'Ostiani, C.; Del Sero, G.; Mosci, P.; Montagnoli, C.; Bacci, A.; Romani, L. Cytokine- and T helper-dependent lung mucosal immunity in mice with invasive pulmonary aspergillosis. J. Infect. Dis. 1998, 178, 1750-1760. [CrossRef] [PubMed]

17. Reikvam, H.; Mosevoll, K.A.; Melve, G.K.; Gunther, C.C.; Sjo, M.; Bentsen, P.T.; Bruserud, O. The pretransplantation serum cytokine profile in allogeneic stem cell recipients differs from healthy individuals, and various profiles are associated with different risks of posttransplantation complications. Biol. Blood Marrow Transplant. 2012, 18, 190-199. [CrossRef]

18. Ceesay, M.M.; Kordasti, S.; Rufaie, E.; Lea, N.; Smith, M.; Wade, J.; Douiri, A.; Mufti, G.J.; Pagliuca, A. Baseline cytokine profiling identifies novel risk factors for invasive fungal disease among haematology patients undergoing intensive chemotherapy or haematopoietic stem cell transplantation. J. Infect. 2016, 73, 280-288. [CrossRef] [PubMed]

19. Lowry, S.F. Cytokine mediators of immunity and inflammation. Arch. Surg. 1993, 128, 1235-1241. [CrossRef]

20. Shamriz, O.; Chandrakasan, S. Update on advances in hematopoietic cell transplantation for primary immunodeficiency disorders. Immunol. Allergy Clin. N. Am. 2019, 39, 113-128. [CrossRef] [PubMed] 
21. Storek, J.; Geddes, M.; Khan, F.; Huard, B.; Helg, C.; Chalandon, Y.; Passweg, J.; Roosnek, E. Reconstitution of the immune system after hematopoietic stem cell transplantation in humans. Semin. Immunopathol. 2008, 30, 425-437. [CrossRef]

22. Ibrahim-Granet, O.; Philippe, B.; Boleti, H.; Boisvieux-Ulrich, E.; Grenet, D.; Stern, M.; Latge, J.P. Phagocytosis and intracellular fate of Aspergillus fumigatus conidia in alveolar macrophages. Infect. Immun. 2003, 71, 891-903. [CrossRef]

23. Diamond, R.D.; Clark, R.A. Damage to Aspergillus fumigatus and Rhizopus oryzae hyphae by oxidative and nonoxidative microbicidal products of human neutrophils in vitro. Infect. Immun. 1982, 38, 487-495. [CrossRef] [PubMed]

24. Mehta, R.S.; Rezvani, K. Immune reconstitution post allogeneic transplant and the impact of immune recovery on the risk of infection. Virulence 2016, 7, 901-916. [CrossRef] [PubMed]

25. Mezger, M.; Kneitz, S.; Wozniok, I.; Kurzai, O.; Einsele, H.; Loeffler, J. Proinflammatory response of immature human dendritic cells is mediated by dectin-1 after exposure to Aspergillus fumigatus germ tubes. J. Infect. Dis. 2008, 197, 924-931. [CrossRef]

26. Ok, M.; Latge, J.P.; Baeuerlein, C.; Ebel, F.; Mezger, M.; Topp, M.; Kurzai, O.; Killian, D.; Kapp, M.; Grigoleit, G.U.; et al. Immune responses of human immature dendritic cells can be modulated by the recombinant Aspergillus fumigatus antigen Aspf1. Clin. Vaccine Immunol. 2009, 16, 1485-1492. [CrossRef]

27. Marischen, L.; Englert, A.; Schmitt, A.L.; Einsele, H.; Loeffler, J. Human NK cells adapt their immune response towards increasing multiplicities of infection of Aspergillus fumigatus. BMC Immunol. 2018, 19, 39. [CrossRef] [PubMed]

28. Armstrong-James, D.P.; Turnbull, S.A.; Teo, I.; Stark, J.; Rogers, N.J.; Rogers, T.R.; Bignell, E.; Haynes, K. Impaired interferongamma responses, increased interleukin-17 expression, and a tumor necrosis factor-alpha transcriptional program in invasive aspergillosis. J. Infect. Dis. 2009, 200, 1341-1351. [CrossRef]

29. Namvar, S.; Warn, P.; Farnell, E.; Bromley, M.; Fraczek, M.; Bowyer, P.; Herrick, S. Aspergillus fumigatus proteases, Asp f 5 and Asp f 13, are essential for airway inflammation and remodelling in a murine inhalation model. Clin. Exp. Allergy 2015, 45, 982-993. [CrossRef] [PubMed]

30. Marr, K.A. Fungal infections in hematopoietic stem cell transplant recipients. Med. Mycol. 2008, 46, 293-302. [CrossRef]

31. Heidegger, S.; van den Brink, M.R.; Haas, T.; Poeck, H. The role of pattern-recognition receptors in graft-versus-host disease and graft-versus-leukemia after allogeneic stem cell transplantation. Front. Immunol. 2014, 5, 337. [CrossRef] [PubMed]

32. Heldt, S.; Prattes, J.; Eigl, S.; Spiess, B.; Flick, H.; Rabensteiner, J.; Johnson, G.; Pruller, F.; Wolfler, A.; Niedrist, T.; et al. Diagnosis of invasive aspergillosis in hematological malignancy patients: Performance of cytokines, Asp LFD, and Aspergillus PCR in same day blood and bronchoalveolar lavage samples. J. Infect. 2018, 77, 235-241. [CrossRef]

33. Goncalves, S.M.; Lagrou, K.; Rodrigues, C.S.; Campos, C.F.; Bernal-Martinez, L.; Rodrigues, F.; Silvestre, R.; Alcazar-Fuoli, L.; Maertens, J.A.; Cunha, C.; et al. Evaluation of bronchoalveolar lavage fluid cytokines as biomarkers for invasive pulmonary Aspergillosis in at-Risk patients. Front. Microbiol. 2017, 8, 2362. [CrossRef]

34. Cunha, C.; Aversa, F.; Romani, L.; Carvalho, A. Human genetic susceptibility to invasive aspergillosis. PLoS Pathog. 2013, 9, e1003434. [CrossRef]

35. Bartemes, K.R.; Kita, H. Innate and adaptive immune responses to fungi in the airway. J. Allergy Clin. Immunol. 2018, 142, 353-363. [CrossRef]

36. Galeas-Pena, M.; McLaughlin, N.; Pociask, D. The role of the innate immune system on pulmonary infections. Biol. Chem. 2019, 400, 443-456. [CrossRef]

37. Re, F.; Strominger, J.L. Toll-like receptor 2 (TLR2) and TLR4 differentially activate human dendritic cells. J. Biol. Chem. 2001, 276, 37692-37699. [CrossRef]

38. Willment, J.A.; Lin, H.H.; Reid, D.M.; Taylor, P.R.; Williams, D.L.; Wong, S.Y.; Gordon, S.; Brown, G.D. Dectin-1 expression and function are enhanced on alternatively activated and GM-CSF-treated macrophages and are negatively regulated by IL-10, dexamethasone, and lipopolysaccharide. J. Immunol. 2003, 171, 4569-4573. [CrossRef]

39. Gringhuis, S.I.; den Dunnen, J.; Litjens, M.; van der Vlist, M.; Wevers, B.; Bruijns, S.C.; Geijtenbeek, T.B. Dectin-1 directs T helper cell differentiation by controlling noncanonical NF-kappaB activation through Raf-1 and Syk. Nat. Immunol. 2009, 10, 203-213. [CrossRef]

40. Mezger, M.; Steffens, M.; Beyer, M.; Manger, C.; Eberle, J.; Toliat, M.R.; Wienker, T.F.; Ljungman, P.; Hebart, H.; Dornbusch, H.J.; et al. Polymorphisms in the chemokine (C-X-C motif) ligand 10 are associated with invasive aspergillosis after allogeneic stem-cell transplantation and influence CXCL10 expression in monocyte-derived dendritic cells. Blood 2008, 111, 534-536. [CrossRef]

41. Cunha, C.; Di Ianni, M.; Bozza, S.; Giovannini, G.; Zagarella, S.; Zelante, T.; D’Angelo, C.; Pierini, A.; Pitzurra, L.; Falzetti, F.; et al. Dectin-1 Y238X polymorphism associates with susceptibility to invasive aspergillosis in hematopoietic transplantation through impairment of both recipient- and donor-dependent mechanisms of antifungal immunity. Blood 2010, 116, 5394-5402. [CrossRef]

42. Gresnigt, M.S.; Cunha, C.; Jaeger, M.; Goncalves, S.M.; Malireddi, R.K.S.; Ammerdorffer, A.; Lubbers, R.; Oosting, M.; Rasid, O.; Jouvion, G.; et al. Genetic deficiency of NOD2 confers resistance to invasive aspergillosis. Nat. Commun. 2018, 9, 2636. [CrossRef]

43. Wojtowicz, A.; Gresnigt, M.S.; Lecompte, T.; Bibert, S.; Manuel, O.; Joosten, L.A.; Rueger, S.; Berger, C.; Boggian, K.; Cusini, A.; et al. IL1B and DEFB1 Polymorphisms increase susceptibility to invasive mold infection after solid-organ transplantation. J. Infect. Dis. 2015, 211, 1646-1657. [CrossRef]

44. Cunha, C.; Goncalves, S.M.; Duarte-Oliveira, C.; Leite, L.; Lagrou, K.; Marques, A.; Lupianez, C.B.; Mesquita, I.; Gaifem, J.; Barbosa, A.M.; et al. IL-10 overexpression predisposes to invasive aspergillosis by suppressing antifungal immunity. J. Allergy Clin. Immunol. 2017, 140, 867-870 e869. [CrossRef] [PubMed] 
45. Chai, L.Y.; de Boer, M.G.; van der Velden, W.J.; Plantinga, T.S.; van Spriel, A.B.; Jacobs, C.; Halkes, C.J.; Vonk, A.G.; Blijlevens, N.M.; van Dissel, J.T.; et al. The Y238X stop codon polymorphism in the human beta-glucan receptor dectin-1 and susceptibility to invasive aspergillosis. J. Infect. Dis. 2011, 203, 736-743. [CrossRef] [PubMed]

46. Zoran, T.; Weber, M.; Springer, J.; White, P.L.; Bauer, J.; Schober, A.; Loffler, C.; Seelbinder, B.; Hunniger, K.; Kurzai, O.; et al. Treatment with etanercept and low monocyte concentration contribute to the risk of invasive aspergillosis in patients post allogeneic stem cell transplantation. Sci. Rep. 2019, 9, 17231. [CrossRef] [PubMed]

47. McCoy, M.K.; Tansey, M.G. TNF signaling inhibition in the CNS: Implications for normal brain function and neurodegenerative disease. J. Neuroinflamm. 2008, 5, 45. [CrossRef]

48. Gattass, C.R.; King, L.B.; Luster, A.D.; Ashwell, J.D. Constitutive expression of interferon gamma-inducible protein 10 in lymphoid organs and inducible expression in T cells and thymocytes. J. Exp. Med. 1994, 179, 1373-1378. [CrossRef]

49. Guo, Y.; Kasahara, S.; Jhingran, A.; Tosini, N.L.; Zhai, B.; Aufiero, M.A.; Mills, K.A.M.; Gjonbalaj, M.; Espinosa, V.; Rivera, A.; et al. During Aspergillus infection, monocyte-derived DCs, neutrophils, and plasmacytoid DCs enhance innate immune defense through CXCR3-dependent crosstalk. Cell Host Microbe 2020, 28, 104-116 e104. [CrossRef]

50. Tramsen, L.; Schmidt, S.; Roeger, F.; Schubert, R.; Salzmann-Manrique, E.; Latge, J.P.; Klingebiel, T.; Lehrnbecher, T. Immunosuppressive compounds exhibit particular effects on functional properties of human anti-Aspergillus Th1 cells. Infect. Immun. 2014, 82, 2649-2656. [CrossRef]

51. Schneider, S.B.; Nishimura, R.D.; Zimmerman, R.P.; Tran, L.; Shiplacoff, J.; Tormey, M.; Contreras, R.; Juillard, G.F. Filgrastim (r-metHuG-CSF) and its potential use in the reduction of radiation-induced oropharyngeal mucositis: An interim look at a randomized, double-blind, placebo-controlled trial. Cytokines Cell. Mol. Ther. 1999, 5, 175-180. [PubMed]

52. Pursell, K.; Verral, S.; Daraiesh, F.; Shrestha, N.; Skariah, A.; Hasan, E.; Pitrak, D. Impaired phagocyte respiratory burst responses to opportunistic fungal pathogens in transplant recipients: In vitro effect of r-metHuG-CSF (Filgrastim). Transpl. Infect. Dis. 2003, 5, 29-37. [CrossRef]

53. Kandalla, P.K.; Sarrazin, S.; Molawi, K.; Berruyer, C.; Redelberger, D.; Favel, A.; Bordi, C.; de Bentzmann, S.; Sieweke, M.H. M-CSF improves protection against bacterial and fungal infections after hematopoietic stem/progenitor cell transplantation. J. Exp. Med. 2016, 213, 2269-2279. [CrossRef] [PubMed]

54. Kimura, F.; Sato, K.; Akiyama, H.; Sao, H.; Okamoto, S.; Kobayashi, N.; Hara, M.; Kawa, K.; Motoyoshi, K.; Japan Marrow Donor Program. M-CSF attenuates severity of chronic GVHD after unrelated BMT. Bone Marrow Transplant. 2012, 47, 426-429. [CrossRef] [PubMed]

55. Romani, L. Cell mediated immunity to fungi: A reassessment. Med. Mycol. 2008, 46, 515-529. [CrossRef] [PubMed]

56. Bigot, J.; Guillot, L.; Guitard, J.; Ruffin, M.; Corvol, H.; Balloy, V.; Hennequin, C. Bronchial epithelial cells on the front line to fight lung infection-causing Aspergillus fumigatus. Front. Immunol. 2020, 11, 1041. [CrossRef]

57. Espinosa, V.; Rivera, A. First line of defense: Innate cell-mediated control of pulmonary Aspergillosis. Front. Microbiol. 2016, 7, 272. [CrossRef]

58. Geissmann, F.; Manz, M.G.; Jung, S.; Sieweke, M.H.; Merad, M.; Ley, K. Development of monocytes, macrophages, and dendritic cells. Science 2010, 327, 656-661. [CrossRef]

59. Perruccio, K.; Bozza, S.; Montagnoli, C.; Bellocchio, S.; Aversa, F.; Martelli, M.; Bistoni, F.; Velardi, A.; Romani, L. Prospects for dendritic cell vaccination against fungal infections in hematopoietic transplantation. Blood Cells Mol. Dis. 2004, 33, 248-255. [CrossRef]

60. Bozza, S.; Gaziano, R.; Spreca, A.; Bacci, A.; Montagnoli, C.; di Francesco, P.; Romani, L. Dendritic cells transport conidia and hyphae of Aspergillus fumigatus from the airways to the draining lymph nodes and initiate disparate Th responses to the fungus. J. Immunol. 2002, 168, 1362-1371. [CrossRef]

61. Bozza, S.; Perruccio, K.; Montagnoli, C.; Gaziano, R.; Bellocchio, S.; Burchielli, E.; Nkwanyuo, G.; Pitzurra, L.; Velardi, A.; Romani, L. A dendritic cell vaccine against invasive aspergillosis in allogeneic hematopoietic transplantation. Blood 2003, 102, 3807-3814. [CrossRef] [PubMed]

62. Grazziutti, M.; Przepiorka, D.; Rex, J.H.; Braunschweig, I.; Vadhan-Raj, S.; Savary, C.A. Dendritic cell-mediated stimulation of the in vitro lymphocyte response to Aspergillus. Bone Marrow Transplant. 2001, 27, 647-652. [CrossRef]

63. Bellocchio, S.; Bozza, S.; Montagnoli, C.; Perruccio, K.; Gaziano, R.; Pitzurra, L.; Romani, L. Immunity to Aspergillus fumigatus: The basis for immunotherapy and vaccination. Med. Mycol. 2005, 43 (Suppl. 1), S181-S188. [CrossRef] [PubMed]

64. Arias, M.; Santiago, L.; Vidal-Garcia, M.; Redrado, S.; Lanuza, P.; Comas, L.; Domingo, M.P.; Rezusta, A.; Galvez, E.M. Preparations for invasion: Modulation of host lung immunity during pulmonary Aspergillosis by Gliotoxin and other fungal secondary metabolites. Front. Immunol. 2018, 9, 2549. [CrossRef] [PubMed]

65. Zelante, T.; De Luca, A.; Bonifazi, P.; Montagnoli, C.; Bozza, S.; Moretti, S.; Belladonna, M.L.; Vacca, C.; Conte, C.; Mosci, P.; et al. IL-23 and the Th17 pathway promote inflammation and impair antifungal immune resistance. Eur. J. Immunol. 2007, 37, 2695-2706. [CrossRef]

66. Zelante, T.; Bozza, S.; De Luca, A.; D’Angelo, C.; Bonifazi, P.; Moretti, S.; Giovannini, G.; Bistoni, F.; Romani, L. Th17 cells in the setting of Aspergillus infection and pathology. Med. Mycol. 2009, 47 (Suppl. 1), S162-S169. [CrossRef]

67. Da Silva, L.B.; Taborda, C.P.; Nosanchuk, J.D. Advances in Fungal Peptide Vaccines. J. Fungi 2020, 6, 119. [CrossRef]

68. Claudia, M.; Bacci, A.; Silvia, B.; Gaziano, R.; Spreca, A.; Romani, L. The interaction of fungi with dendritic cells: Implications for Th immunity and vaccination. Curr. Mol. Med. 2002, 2, 507-524. [CrossRef] 
69. Xu, X.; Han, M.; Li, T.; Sun, W.; Wang, D.; Fu, B.; Zhou, Y.; Zheng, X.; Yang, Y.; Li, X.; et al. Effective treatment of severe COVID-19 patients with tocilizumab. Proc. Natl. Acad. Sci. USA 2020, 117, 10970-10975. [CrossRef]

70. Gupta, S.; Wang, W.; Hayek, S.S.; Chan, L.; Mathews, K.S.; Melamed, M.L.; Brenner, S.K.; Leonberg-Yoo, A.; Schenck, E.J.; Radbel, J.; et al. Association between early treatment with Tocilizumab and mortality among critically Ill patients with COVID-19. JAMA Intern. Med. 2021, 181, 41-51. [CrossRef] 